International Journal of Current Advanced Research

ISSN: O: 2319-6475, ISSN: P: 2319 - 6505, Impact Factor: SJIF: 5.995

Available Online at www.journalijcar.org

Volume 6; Issue 4; April 2017; Page No. 3201-3202

DOI: http://dx.doi.org/10.24327/ijcar.2017.3202.0224

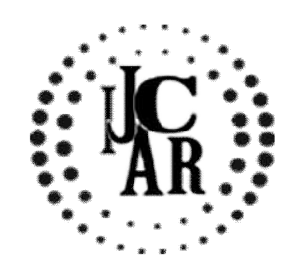

Research Article

\title{
PRELIMINARY PHYTOCHEMICAL ANALYSIS AND TOTAL PHENOL CONTENT OF WALNUT OIL
}

\section{Shunmugam Kumar Mangal C and SoharaParveen N}

Saveetha Dental College- Chennai 77

\begin{tabular}{l}
\hline A R T I C L E I N F O \\
Article History: \\
Received $11^{\text {th }}$ January, 2017 \\
Received in revised form $19^{\text {th }}$ February, 2017 \\
Accepted $22^{\text {nd }}$ March, 2017 \\
Published online $28^{\text {th }}$ April, 2017
\end{tabular}

\section{Key words:}

Phenol Content, Walnut Oil

\begin{abstract}
A B S T R A C T
Aim: To estimate the total phenol and phytochemical content of walnut oil

Objective: To determine total phenols and phytochemicals present in walnut oil

Background: A walnut is a species belongs to the nut Family Juglandaceae .The walnut is nutrient-dense with protein and essential fatty acids. Walnut oil is rich in polyunsaturated fatty acid like alpha linlenic acid and linoleic acid. Phytochemicals are chemical compounds naturally present in plants. They found in fruits, nuts, vegetables, legumes and grains and responsible for the taste, smell and color of the plant based foods. Most of them have antioxidants activity and protect our cells against oxidative damage and reduce the risk of developing certain types of cancer

Reasons: Frequent nut intake is associated with protective effects against cardiovascular diseases. In addition to the generally high contents of unsaturated fatty acids, polyphenol compounds seem to be also implicated in health promoting effects of nuts due to their antioxidant properties.
\end{abstract}

Copyright $₫ 2017$ Shunmugam Kumar Mangal $\boldsymbol{C}$ and SoharaParveen $\boldsymbol{N}$. This is an open access article distributed under the Creative Commons Attribution License, which permits unrestricted use, distribution, and reproduction in any medium, provided the original work is properly cited.

\section{INTRODUCTION}

The scientific name of walnut is Juglansregia. It's a rich source of proteins and essential fatty acids. In this topic we will find the phytochemicals present and the total phenol content of walnut oil. The presence of Phytochemicals in plants help in curing diseases and help in healing (1). They are present in the leaves, vegetables, fruits and seeds of the plant.Chlorophyll, proteins and common sugars are included in primary constituents and secondary compounds have terpenoid, alkaloids and phenolic compounds [2]. Terpenoids exhibit various important pharmacological activities i.e., anti-in ammatory, anti- cancer, anti-malarial, inhibition of cholesterol synthesis, anti-viral and anti-bacterial activities [3]. And due to the presence of PUFA in them they help in protecting the body from cardiovascular problems.

\section{MATERIALS AND METHODS}

\section{Plant materials}

Walnut oil is taken as plant material

\section{Chemicals}

Fehling solution A and Fehling solution B, ethanol, distill water, aqueous $\mathrm{HCl}$, methanol, chloroform, concentrated sulphuric acid, Ammonia solution, picric acid, Hexane.

\footnotetext{
*Corresponding author: Shunmugam Kumar Mangal C Saveetha Dental College- Chennai 77
}

\section{Preparation of the plant extract}

The leaves of the selected plants were removed from the plants and then washed under running tap water to remove dust. e plant samples were then air dried for few days and the leaves were crushed into powder and stored in polythene bags for use. The plant powder was taken in a test tube and distilled water was added to it such that plant powder soaked in it and shaken well. The solution then filtered with the help of filter paper and filtered extract of the selected plant samples were taken and used for further phytochemical analysis. As the plant material we are using for our research is oil there is no need to prepare the extract.

\section{Test for phlobatannins}

Plant powder sample was mixed with distill water in a test tube, then shaked it well, and ltered to take plant extract. en to each plant extract, $1 \%$ aqueous hydrochloric acid was added and each plant sample was then boiled with the help of Hot plate stirrer. Formation of red colored precipitate con rmed a positive result.

\section{Test for reducing Sugar}

An amount of $0.50 \mathrm{~g}$ of selected plant sample was added in 5 $\mathrm{ml}$ of distilled water. en $1 \mathrm{ml}$ of ethanol mixed in plant extract. A er that we took $1 \mathrm{ml}$ of Fehling solution A and $1 \mathrm{ml}$ of Fehling solution B in a test tube, heated it to boiling and then poured it in the aqueous ethanol extract. When color reaction was observed, it shows a positive result. 


\section{Test for terpenoids}

An amount of $0.8 \mathrm{~g}$ of selected plant sample was taken in a test tube, then poured $10 \mathrm{ml}$ of methanol in it, shaken well and ltered to take $5 \mathrm{ml}$ extract of plant sample. en $2 \mathrm{ml}$ of chloroform were mixed in extract of selected plant sample and $3 \mathrm{ml}$ of sulphuric acid were added in selected sample extract. Formation of reddish brown color indicates the presence of terpenoids in the selected plants.

\section{Test for flavonoids}

For the conformation of flavonoid in the selected plants, 0.5 $\mathrm{g}$ of each selected plant extract were added in a test tube and $10 \mathrm{ml}$ of distill water, $5 \mathrm{ml}$ of dilute ammonia solution were added to a portion of the aqueous filtrate of each plant extract followed by addition of $1 \mathrm{ml}$ concentrated $\mathrm{H} 2 \mathrm{~S} 04$. Indication of yellow color shows the presence of flavonoids in each extract.

The total phenolics content of $\mathrm{H}$. radicata was estimated using Folin-Ciocalteau reagent by the method of Sidduraju and Becker [19]. About $20 \mu \mathrm{g}$ of leaf and root extracts were taken separately and it was made up to $1 \mathrm{~mL}$ with distilled water. Then $500 \mu \mathrm{L}$ of diluted Folins-phenol reagent (1:1 ratio with water) and $2.5 \mathrm{~mL}$ of sodium carbonate $\mathrm{Na} 2 \mathrm{CO} 3$ (20\%) were added. The mixture was shaken well and incubated in dark condition for $40 \mathrm{~min}$ for the development of colour. After incubation, the absorbance was measured at $725 \mathrm{~nm}$. A calibration curve of gallic acid was constructed and linearity was obtained in the range of $10-50 \mu \mathrm{g} / \mathrm{mL}$. The total phenolics content in the plant extracts were expressed as $\mathrm{mg}$ of gallic acid equivalent (mg GAE/g extract) by using the standard curve.

Total phenolics content

\section{RESULT}

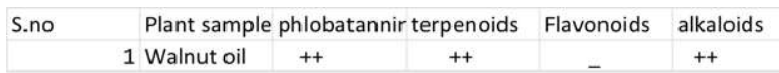

The study has revealed the presence of phytochemicals hence walnut can be considered to have certain medical properties. Other than flavonoids all other components are present in walnut oil. And the total phenol content of walnut oil has also been estimated

Nuts Total phenols

Walnut (oil) $\quad 12 \mathrm{mg}$ of Gallic acid /1g of walnut oil

\section{CONCLUSION}

The selected ten medicinal plants are the source of the secondary metabolites i.e., alkaloids, flavonoids, terpenoids, phlobatannins and reducing sugars. Medicinal plants play a vital role in preventing various diseases. e antidiuretic, antiinflammatory, antianalgesic, anti- cancer, anti-viral, antimalarial, anti-bacterial and anti-fungal activities of the medicinal plants are due to the presence of the above mentioned secondary metabolites. Medicinal plants are used for discovering and screening of the phytochemical constituents which are very helpful for the manufacturing of new drugs.

\section{Reference}

1. Phytochemical Analysis of Medicinal Plants Occurring in Local Area of Mardan

2. Phytochemical analysis and evaluation of leaf and root parts of the medicinal herb, Hypochaerisradicata L. for in vitro antioxidant activities

3. Comparison of phenol content and antioxidant capacity of nuts

4. Scientifically Proven Health Benefits of Oil No. 80

5. Begum S, Ahmed M, Siddiqui BS, Khan A, Saify ZS, et al. (1997) Triterpenes, A sterol and Amonocyclic alcohol from Momordicacharantia. Phytochem 44: 1313-1320.

6. Okabe H, Miyahara Y, Yamauci T (1982) Studies on the constituents of MomordicacharantiaL. ChemPharm Bull 30: 4334-4340.

7. Kimura Y, Akihisa T, Yuasa N, Ukiya M, Suzuki T, et al. (2005) Cucurbitane-type triterpenoids from the fruit of Momordicacharantia. J Nat Prod 68: 807-809.

8. Chang CI, Chen CR, Liao YW, Cheng HL, Chen YC, et al. (2008) Cucurbitane- type triterpenoids from the stems of momordicacharantia. J Nat Prod 71: 13271330 .

9. Akihisa T, Higo N, Tokuda H, Ukiya M, Akazawa H, et al. (2007) Cucurbitane- type triterpenoids from the fruits of Momordicacharantia and their cancer chemopreventive effects. J Nat Prod 70: 1233-1239.

10. Kim HB, Bang HS, Lee HW, Seuk YS, Sung GB (1999) Chemical characteristics of mulberry syncarp. Korean J Med. Crop Sci 47: 3206-3209.

11. Osman AM, Younes ME, Sheta AE (1974) Triterpenoids of the leaves of Psidiumguajava. Phytochem 13: 2015-2016.

12. Begum S, Hassan SI, Siddiqui BS, Shaheen F, Ghayur $\mathrm{MN}$, et al. (2002) Triterpenoids from the leaves of Psidiumguajava. Phytochemistry 61: 399-403.

13. Caccioni DRL, Tonini G, Guizzardi M (2002) In vitro antifungal activity of some South African medicinal plants. South Afr J Bot 68: 72-76.

\section{How to cite this article:}

Shunmugam Kumar Mangal C and SoharaParveen N (2017) ' Preliminary Phytochemical Analysis And Total Phenol Content Of Walnut Oil', International Journal of Current Advanced Research, 06(04), pp. 3201-3202.

DOI: http://dx.doi.org/10.24327/ijcar.2017.3202.0224 